\title{
Role of preoperative C-reactive protein value and neutrophil ratio in the determination of conversion from laparoscopic appendectomy to open appendectomy
}

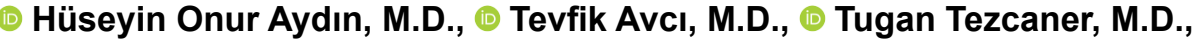

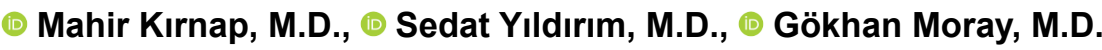

Department of General Surgery, Başkent University Faculty of Medicine, Ankara-Turkey

\begin{abstract}
BACKGROUND: In this study, we aimed to investigate the factors causing conversion from laparoscopic appendectomy (LA) to open appendectomy $(\mathrm{OA})$ in patients with acute appendicitis and to investigate the role of preoperative $C$ reactive protein (CRP) and neutrophil ratio in this conversion and determine a cut-off point for these parameters.
\end{abstract}

METHODS: Records of patients who underwent LA due to acute appendicitis at our general surgery department between January $201 \mathrm{I}$ and January 2017 were retrospectively evaluated. The preoperative American Society of Anesthesiology (ASA) scores, Alvarado scores, white blood cell count, C-reactive protein level, and neutrophil ratio were evaluated.

RESULTS: LA was performed in 394 patients with an initial diagnosis of acute appendicitis. A conversion to OA (cOA) was performed in 17 patients (4.31\%). A CRP value of $\geq 108.5 \mathrm{mg} / \mathrm{L}$ and a neutrophil ratio of $\geq 81.5 \%$ were found to be statistically significant for the $c O A(p<0.001)$.

CONCLUSION: Our study results showed that male gender, age, elevated neutrophil ratio, and CRP value were the main risk factors for cOA in patients who were scheduled for LA due to acute appendicitis.

Keywords: C-reactive protein; conversion to open surgery; laparoscopic appendectomy; neutrophil.

\section{INTRODUCTION}

Acute appendicitis is one of the most common causes of acute abdominal pain. It is observed at a rate of $8.6 \%$ in males and $6.7 \%$ in females. ${ }^{[I]}$ Before laparoscopic cholecystectomy, laparoscopic appendectomy (LA) was defined by Semm in 1983. [2] It may have a rapid duration of recovery, improved cosmetic results, and shorter duration of hospital stay compared to open appendectomy (OA); however, it has several disadvantages, such as a long duration of operation, high cost, and postoperative risk of intra-abdominal abscess development. ${ }^{[3]}$ In the past two decades, with the increased knowledge and skills in laparoscopic techniques, LA has gained popularity for the treatment of acute appendicitis, and $75 \%$ of all appendectomies are now being performed through laparoscopy. ${ }^{[4]}$ However, there is still no consensus with regard to which technique is superior.

Several factors influence the conversion from LA to OA, including advanced age, male gender, obesity, intra abdominal abscess or perforation, and adhesions due to a previous abdominal surgery. ${ }^{[5]}$ The conversion from the laparoscopic technique to the open technique leads to morbidities, such as prolongation of the operation time, increased cost, additional incision, prolonged duration of hospital stay, and postoperative wound infection. Therefore, many studies have been performed during the preoperative assessment to determine the most suitable technique for an individual patient. Although

Cite this article as: Aydın HO, Avcı T, Tezcaner T, Kırnap M, Yıldırım S, Moray G. Role of preoperative C-reactive protein value and neutrophil ratio in the determination of conversion from laparoscopic appendectomy to open appendectomy. Ulus Travma Acil Cerrahi Derg 2018;24:429-433.

Address for correspondence: Hüseyin Onur Aydın, M.D.

Adres bilgisi: Başkent Üniversitesi Tıp Fakültesi, Genel Cerrahi Anabilim Dalı, Ankara, Turkey

Tel: +90 312 - 2152629 E-mail: dronuraydin@hotmail.com 
several factors that affect the conversion have been defined to date, there is still no certain algorithm.

In the present study, we aimed to evaluate the factors affecting conversion from LA to OA in patients with acute appendicitis. For this purpose, we aimed to present the effect of preoperative characteristic features and laboratory findings on conversion from LA to OA.

\section{MATERIALS AND METHODS}

The medical records of all consecutive patients aged above 18 years who had the diagnosis of acute appendicitis between January 20II and January 2017 were retrospectively analyzed. The patients who had no abdominal surgery history, no malignancy history, and no perforation findings in a radiological evaluation were included in the study. Among these patients, the file information of patients who underwent LA was evaluated. Patients were divided into two groups according to those completing appendectomy through laparoscopy or those converted from LA to OA.

The study was approved by Baskent University Institutional Review Board (Project No: KA 17/9I) and conducted in accordance with the principles of the Declaration of Helsinki. Written informed consent was obtained from each patient.

LA was performed by a general surgeon who had at least a 5-year experience in laparoscopy or by a general surgery resident under the supervision of an experienced general surgeon. All operations were performed in a supine Trendelenburg and right side-up position. After positioning the patient, three trocars were placed in the umbilical region (camera port, $10-12 \mathrm{~mm}$ ), suprapubic region (instrument port, $10-12 \mathrm{~mm}$ ), and left lower quadrant (instrument port, $5 \mathrm{~mm}$ ), and appendectomy was performed. The appendix stump was ligated with two 2/0 non-absorbable loops, which were prepared extracorporeally, and the appendix was removed using an endobag. In the patients who had a conversion to OA (cOA), a Mc Burney incision was performed on the right lower quadrant. After ligating the appendix stump with a $2 / 0$ non-absorbable suture, appendectomy was performed. In both groups, at the end of the operation, the abdominal cavity was irrigated with sterile isotonic solution, and in the presence of peritoneal inflammation and intra-abdominal abscess or perforation, intra abdominal drainage was performed.

Preoperative American Society of Anesthesiology (ASA) scores, Alvarado scores, white blood cell count (WBC), $\mathrm{C}$-reactive protein (CRP) value, and neutrophil ratio were recorded. In addition, the presence of inflammation in the appendix, peritonitis, and intra-abdominal abscess, and the presence of appendix perforation and retrocecal appendix were evaluated. Postoperative pathology reports were examined.

A statistical analysis was performed using the SPSS version
19 software program (IBM Corp., Armonk, NY, USA). Demographic and clinical characteristics were expressed as frequency or percentage for categorical data, as mean standard deviation $( \pm S D)$ for continuous parametric variables, and as median (interquartile ranges) for continuous non-parametric variables. The differences in preoperative and postoperative characteristics between the groups were evaluated using the Pearson's chi-square test, two-sample t-test, Wilcoxon rank sum test, analysis of variance (ANOVA), or Kruskal-Wallis test, as appropriate. A univariate regression analysis was used to identify significant factors associated with cOA among patients who received LA and cOA. The receiver operating characteristic (ROC) analysis and area-under-curve (AUC) was performed to identify the cut-off values for WBC, CRP, and neutrophil ratio for cOA. A p value of $<0.05$ was considered statistically significant.

\section{RESULTS}

A total of 669 patients were treated for acute appendicitis. Among the 394 patients who underwent LA, 208 (52.79\%) were females. The mean age of all patients was 35.8 13.87 years. Further, cOA was performed in 17 patients $(4.31 \%)$. The mean age of the patients who converted to OA was $42.47 \pm 21$. I years and that of patients who underwent $L A$ was $35.59 \pm 13.4$ years. The mean age of patients who converted to OA was significantly higher than the patients who underwent LA $(p<0.05)$. Male gender was found to be more common in the cOA group $(p<0.05)$. Demographic and clinical characteristics of patients are presented in Table I.

The mean duration of the symptom onset was $1.63 \pm 1.30$ days (range, I-10 days). The most common diagnostic method was ultrasonography in $46.2 \%$ patients. The most common

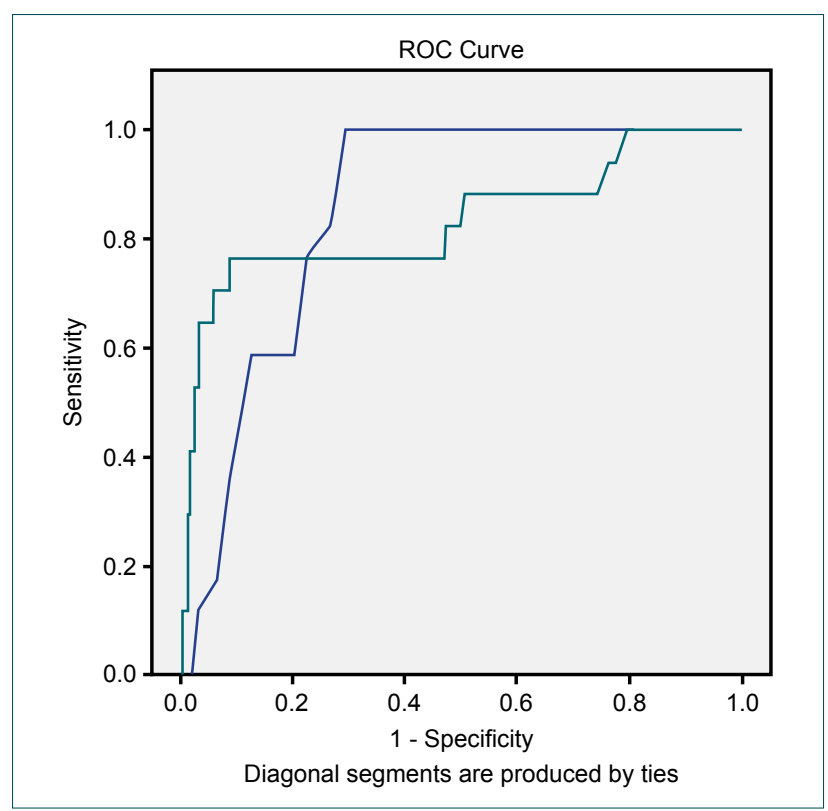

Figure 1. ROC Curve analysis. AUC Neutrophil: 0.854; AUC CRP: 0.832 . 
Table I. Demographic and clinical characteristics

\begin{tabular}{|c|c|c|c|}
\hline & Laparoscopic appendectomy & Conversion to open appendectomy & $\mathbf{p}$ \\
\hline Number of patients & 377 & 17 & \\
\hline Age (years) & $35.59 \pm 13.4$ & $42.47 \pm 21.1$ & $<0.05$ \\
\hline Male/female & $174 / 204$ & $13 / 4$ & $<0.05$ \\
\hline Alvorado score & $6.23 \pm 1.71$ & $6.88 \pm 1.65$ & \\
\hline \multicolumn{4}{|l|}{ ASA Score } \\
\hline $\mathrm{I} / 2$ & 290/7I & $16 / 0$ & \\
\hline $3 / 4$ & $11 / 4$ & $2 / 0$ & \\
\hline \multicolumn{4}{|l|}{ Surgical findings, n (\%) } \\
\hline Normal & $9(2.4)$ & 0 & \\
\hline Inflammation & $325(86.2)$ & $3(17.6)$ & \\
\hline Acute appendicitis & $12(3.2)$ & $0(0)$ & \\
\hline Intra-abdominal abscess & $6(1.6)$ & I (5.9) & \\
\hline Perforated appendicitis & $9(2.4)$ & $9(52.9)$ & $<0.05$ \\
\hline Retrocecal appendicitis & $16(4.2)$ & $4(23.5)$ & \\
\hline \multicolumn{4}{|l|}{ Complication, n (\%) } \\
\hline None & $362(96)$ & II (64.7) & $<0.05$ \\
\hline Wound enfection & $9(2.4)$ & I (5.9) & \\
\hline Intraabdominal abscess & $4(1.1)$ & $4(23.5)$ & \\
\hline Postoperative ileus & $\mathrm{I}(0.3)$ & I (5.9) & \\
\hline Stump leakage & I $(0.3)$ & $0(0)$ & \\
\hline \multicolumn{4}{|l|}{ Pathology, n (\%) } \\
\hline Normal appendix & $39(10.3)$ & I (5.9) & \\
\hline Acute appendicitis & $314(83.3)$ & $13(76.5)$ & $>0.05$ \\
\hline Chronic inflammation & $4(1.1)$ & I (5.9) & \\
\hline Mucoceles & $6(1.6)$ & $0(0)$ & \\
\hline Carcinoma & $4(1.1)$ & $0(0)$ & \\
\hline Perforated appendicitis & $10(2.7)$ & $2(11.8)$ & \\
\hline Duration of hospital stay (days) & $1.4 I \pm 0.96$ & $4.24 \pm 2.16$ & $<0.05$ \\
\hline
\end{tabular}

Table 2. Preoperative laboratory findings

\begin{tabular}{lccc}
\hline & LA & COA & p \\
\hline WBC $(\mathrm{mg} / \mathrm{dL})$ & $13.044 \pm 4039$ & $14.229 \pm 390$ & 0.237 \\
CRP $(\mathrm{mg} / \mathrm{L})$ & $44.0 \pm 51.04$ & $162.59 \pm 100.4$ & $<0.001$ \\
Neutrophil $(\%)$ & $75.5 \pm 10.4$ & $86.4 \pm 3.2$ & $<0.001$
\end{tabular}

LA: Laparoscopic appendectomy; cOA: Conversion to open appendectomy; WBC: White blood cell; CRP: C-reactive protein.

surgical finding was inflammation surrounding the appendix (83.2\%), and the most common pathological result was acute appendicitis (83\%). The mean duration of hospital stay was $1.41 \pm 0.96$ days in the LA group and $4.24 \pm 2.16$ days in the cOA group, indicating a significantly higher duration in the cOA group $(p<0.01)$.
Table 3. Factors influencing to conversion from LA to cOA

\begin{tabular}{lcccc}
\hline & & p & Odds ratio & $95 \% \mathrm{Cl}$ \\
\hline CRP $(\mathrm{mg} / \mathrm{L})$ & $\geq 108.5^{*}$ & $<0.00 \mathrm{I}$ & $\mathrm{I} .0 \mathrm{I}$ & $\mathrm{I} .0-\mathrm{I} .02$ \\
Neutrophil $(\%)$ & $\geq 81.5^{*}$ & $<0.00 \mathrm{I}$ & $\mathrm{I} .32$ & $\mathrm{I} .13-\mathrm{I} .54$ \\
\hline
\end{tabular}

*ROC curve cut-off points. ROC: receiver operating characteristic; LA: Laparoscopic appendectomy; COA: Conversion to open appendectomy; $\mathrm{Cl}$ : Confidence interval; CRP: C-reactive protein.

There was a higher rate of $\mathrm{COA}(52.9 \%)$ observed in patients with appendix perforation detected during the surgery, indicating a statistical significance $(p<0.05)$. The preoperative Alvarado scores, ASA scores, and the duration of onset of symptoms had no effect on $c O A$ ( $p>0.05)$. WBC count was found to be higher in the COA group compared to the LA 
group (LA, I $3.044 \pm 4.039 \mathrm{mg} / \mathrm{dL}$; cOA, I4.229 $\pm 3.902 \mathrm{mg} /$ $\mathrm{dL})$ although this difference was not statistically significant $(p=0.816)$. In addition, CRP value and neutrophil ratio were found to be significantly higher in the cOA group $(p<0.001$; Table 2). ROC curve analysis and AUC for preoperative CRP and neutrophil ratio revealed that a CRP value of $\geq 108.5$ $\mathrm{mg} / \mathrm{L}$ and a neutrophil ratio of $\geq 81.5 \%$ were found to be statistically significant for cOA (Table 3 and Fig. I).

\section{DISCUSSION}

With the introduction of recent technical development and instruments, major advances have been achieved in laparoscopic surgery within the past decade. Considering the developments, LA is safely used for the treatment of acute appendicitis. However, the difference in superiority between LA and $O A$ is uncertain. In the light of literature data, for patients undergoing LA, oral intake can be started sooner, and there is less analgesic requirement and shorter hospital stay. ${ }^{[6,7]}$ However, cOA leads to increased costs, additional incision requirement, and prolonged hospital stay. ${ }^{[8]}$ In the current study, we showed that the hospital stay in the cOA group was longer than that in the LA group. Although there was no difference in the postoperative complications between the two groups, the presence of an additional incision and the requirement of an additional antibiotic therapy in case of intra abdominal inflammation causing conversion led to the prolongation of hospital stay, which is consistent with previous study findings. ${ }^{[5]}$

In the present study, cOA was demonstrated in 17 patients (4.31\%) who underwent LA. This ratio is below 10\%, which is consistent with the results reported in a previous meta analysis. ${ }^{[3]}$ In addition, male gender was found to be $76.5 \%$ in the cOA group, and patients who converted to OA were found to be older compared to the LA group; these results were statistically significant $(p<0.05)$. Similarly, previous studies showed that male gender and age $\geq 40$ years were risk factors for cOA. ${ }^{[4,5]}$ More frequent diagnostic laparoscopy in female patients with right lower abdominal pain could be a reason for the early diagnosis of acute appendicitis in female patients. ${ }^{\left[{ }^{9]}\right.}$ It has been reported that perforated appendicitis is seen more frequently in male patients, thereby increasing the rates of $\mathrm{COA}$ in male patients. ${ }^{[10]}$ Our results also showed that the conversion was more frequent in patients with appendix perforation.

Although the sensitivity of leukocytosis detection in peripheral blood is high in acute appendicitis, the specificity is known to be low because it is a known marker of inflammation. ${ }^{\left[{ }^{11]}\right.}$ In a study by Farooqui et al., ${ }^{[12]}$ it was demonstrated that the WBC count was higher, particularly in perforated appendicitis. In the current study, we found that the preoperative WBC count was higher in the cOA group. However, this elevation did not cause a statistically significant difference between the two groups. Although leukocytosis is an adjuvant test used in the diagnosis of acute appendicitis, laparoscopy can be reliably performed in complicated appendicitis due to the advances in laparoscopic techniques. A meta-analysis by Yu et al. ${ }^{[13]}$ showed that surgical-site infections, time to start oral feeding, and lengths of hospital stay were shorter in patients who underwent LA due to the complicated acute appendectomy compared to those who underwent OA.

There may be an increase in the neutrophil ratio during bacterial infections. In several studies, the sensitivity of elevation of the neutrophil ratio was found to be between $85 \%$ and $98 \%$ in the diagnosis of acute appendicitis. ${ }^{[14,15]}$ The neutrophil ratio was reported as an adjuvant parameter in the diagnosis of acute appendicitis; we found significantly higher rates in the cOA group compared to the LA group in our study $(p<0.00 I)$. This can be attributed to the development of diffuse peritonitis, intra abdominal abscess, or plastrone appendicitis due to bacterial translocation. According to the ROC analysis, in addition, a neutrophil ratio of $\geq 81.5 \%$ was significant in the conversion to OA.

It is well established that high CRP values are reliable in the diagnosis of acute appendicitis. ${ }^{[16]}$ In literature, several studies have reported that CRP values were higher in patients who underwent cOA compared to those who underwent LA. ${ }^{[17,18]}$ Similarly, in the current study, the CRP values in the cOA group were significantly higher than those in the LA group $(p<0.00 \mathrm{I})$. According to the ROC analysis, a CRP value of $\geq 108.5 \mathrm{mg} / \mathrm{L}$ was a risk factor for the conversion to $\mathrm{OA}$. This result may be explained by the high CRP value in patients with severe intra-abdominal inflammation that prevents laparoscopic dissection.

Our study has several limitations. The retrospective nature and the heterogeneity of patient groups are limiting factors. Also, the decision of conversion to OA was determined by the attending surgeon and not by the apparent criteria. Despite these factors, we aimed to show statistically significant differences between the groups.

In conclusion, male gender, age, a neutrophil ratio of $\geq 81.5 \%$, and a CRP value of $\geq 108.5 \mathrm{mg} / \mathrm{L}$ were risk factors for OA in patients who were scheduled for LA due to acute appendicitis. Therefore, patients with such risk factors can be switched from LA to OA.

\section{Conflict of interest: None declared.}

\section{REFERENCES}

1. Addiss DG, Shaffer N, Fowler BS, Tauxe RV. The epidemiology of appendicitis and appendectomy in the United States. Am J Epidemiol 1990;132:910-25. [CrossRef]

2. Semm K. Endoscopic appendectomy. Endoscopy 1983;15:59-64.

3. Sauerland S, Jaschinski T, Neugebauer EA. Laparoscopic versus open surgery for suspected appendicitis. Cochrane Database Syst Rev 2010:CD001546. 
4. Masoomi H, Nguyen NT, Dolich MO, Mills S, Carmichael JC, Stamos MJ. Laparoscopic appendectomy trends and outcomes in the United States: data from the Nationwide Inpatient Sample (NIS), 2004-2011. Am Surg 2014;80:1074-7.

5. Finnerty BM, Wu X, Giambrone GP, Gaber-Baylis LK, Zabih R, Bhat A, et al. Conversion-to-open in laparoscopic appendectomy: A cohort analysis of risk factors and outcomes. Int J Surg 2017;40:169-75. [CrossRef]

6. Nana AM, Ouandji CN, Simoens C, Smets D, Mendes da Costa P. Laparoscopic appendectomies: results of a monocentric prospective and non-randomized study. Hepatogastroenterology 2007;54:1146-52.

7. Yeh CC, Wu SC, Liao CC, Su LT, Hsieh CH, Li TC. Laparoscopic appendectomy for acute appendicitis is more favorable for patients with comorbidities, the elderly, and those with complicated appendicitis: a nationwide population-based study. Surg Endosc 2011;25:2932-42.

8. Chung RS, Rowland DY, Li P, Diaz J. A meta-analysis of randomized controlled trials of laparoscopic versus conventional appendectomy. Am J Surg 1999;177:250-6. [CrossRef]

9. Laine S, Rantala A, Gullichsen R, Ovaska J. Laparoscopic appendectomy-is it worthwhile? A prospective, randomized study in young women. Surg Endosc 1997;11:95-7. [CrossRef]

10. Larsson PG, Henriksson G, Olsson M, Boris J, Ströberg P, Tronstad $\mathrm{SE}$, et al. Laparoscopy reduces unnecessary appendicectomies and improves diagnosis in fertile women. A randomized study. Surg Endosc 2001;15:200-2. [CrossRef]
11. Hallan S, Asberg A, Edna TH. Additional value of biochemical tests in suspected acute appendicitis. Eur J Surg 1997;163:533-8.

12. Farooqui W, Pommergaard HC, Burcharth J, Eriksen JR. The diagnostic value of a panel of serological markers in acute appendicitis. Scand J Surg 2015;104:72-8. [CrossRef]

13. Yu MC, Feng YJ, Wang W, Fan W, Cheng HT, Xu J. Is laparoscopic appendectomy feasible for complicated appendicitis? A systematic review and meta-analysis. Int J Surg 2017;40:187-97. [CrossRef]

14. Shafi SM, Afsheen M, Reshi FA. Total leucocyte count, C-reactive protein and neutrophil count: diagnostic aid in acute appendicitis. Saudi J Gastroenterol 2009;15:117-20. [CrossRef]

15. Yang HR, Wang YC, Chung PK, Chen WK, Jeng LB, Chen RJ. Role of leukocyte count, neutrophil percentage, and C-reactive protein in the diagnosis of acute appendicitis in the elderly. Am Surg 2005;71:344-7.

16. Wu HP, Lin CY, Chang CF, Chang YJ, Huang CY. Predictive value of C-reactive protein at different cutoff levels in acute appendicitis. Am J Emerg Med 2005;23:449-53. [CrossRef]

17. Abe T, Nagaie T, Miyazaki M, Ochi M, Fukuya T, Kajiyama K. Risk factors of converting to laparotomy in laparoscopic appendectomy for acute appendicitis. Clin Exp Gastroenterol 2013;6:109-14. [CrossRef]

18. Antonacci N, Ricci C, Taffurelli G, Monari F, Del Governatore M, Caira A, et al. Laparoscopic appendectomy: Which factors are predictors of conversion? A high-volume prospective cohort study. Int J Surg 2015;21:103-7. [CrossRef]

\section{ORİJINAL ÇALIŞMA - ÖZET}

\section{Ameliyat öncesi C-reaktif protein değeri ve nötrofil yüzdesinin laparoskopik apendektomiden açık apendektomiye konversiyonu belirlemedeki yeri}

\section{Dr. Hüseyin Onur Aydın, Dr. Tevfik Avcı, Dr. Tugan Tezcaner, Dr. Mahir Kırnap, Dr. Sedat Yıldırım, Dr. Gökhan Moray}

Başkent Üniversitesi Tıp Fakültesi, Genel Cerrahi Anabilim Dalı, Ankara

AMAÇ: Çalışmamızda amacımız akut apandisit nedeniyle laparoskopik apendektomi (LA) uygulanan hastalarda açık apendektomiye (AA) konversiyona neden olan faktörleri incelenmektir. Ameliyat öncesi laboratuvar bulgularından C-reaktif protein (CRP) ve nötrofil yüzdelerinin konversiyona etkisini incelemek ve bu değerler için kesim değeri belirlemektir.

GEREÇ VE YÖNTEM: Merkezimizde, Ocak 201 I-Ocak 2017 yılları arasında akut apandisit nedeniyle LA uygulanan hastaların dosya bilgileri geriye dönük olarak incelendi. Ameliyat öncesi American Society of Anesthesiology skoru, Alvorado skoru, beyaz küre sayısı, CRP düzeyi ve nötrofil yüzdesi değerlendirildi.

BULGULAR: Akut apandisit ön tanısıyla 394 hastaya LA uygulandı. On yedi (\%4.3I) hastada AA'ya konversiyon tespit edildi. C-reaktif protein değeri için 108.5 mg/L ve üstü değerler; nötrofil yüzdesi için \%8। .5 ve üstü değerlerde LA'dan AA'ya konversiyonun istatistiksel olarak anlamlı olduğu görüldü.

TARTIŞMA: Akut apandisit nedeniyle LA uygulanan hastalarda erkek cinsiyet, yaş, nötrofil yüzdesi ve CRP değerinin yüksek olması LA'dan AA'ya konversiyonda risk faktörü olduğu görülmüştür.

Anahtar sözcükler: Açık cerrahiye konversiyon; C-reaktif protein; laparoskopik apendektomi; nötrofil.

Ulus Travma Acil Cerrahi Derg 2018;24(5):429-433 doi: 10.5505/tjtes.2018.68705 